\title{
MILENIAL INTENTION ON SOCIAL MEDIA
}

\author{
Selfia Ratna Kasih ${ }^{1}$, Asep M. Ramdan ${ }^{2}$, Acep Samsudin ${ }^{3}$ \\ Universitas Muhammadiyah Sukabumi ${ }^{1,2,3}$ \\ selfiaratnakasih123@ummi.ac.id ${ }^{1}$
}

\begin{abstract}
ABSTRAK
Tujuan dari penelitian ini adalah untuk mengukur seberapa besar pengaruh media sosial instagram dan kepercayaan konsumen terhadap minat beli kaum milenial.Variabel penelitian ini yaitu media sosial instagram (X1), Kepercayaan konsumen (X2) dan minat beli kaum milenial (Y). Metode yang digunakan pada penelitian ini yaitu metode penelitian kuantitatif dengan pendekatan asosiatif, dengan melakukan penyebaran kuesioner online sebanyak 200 kepada kaum milenial yang berusia produktif. Adapun teknik analisis yang digunakan untuk menguji hipotesis pada penelitian ini ialah dengan analisis jalur. Hasil uji hipotesis menunjukan media sosial intagram dan kepercayaan konsumen memiliki pengaruh yang signifikan terhadap minat beli kaum milenial dan hasil pengujian hipotesis mediasi menunjukan bahwa variabel kepercayaan konsumen memediasi media sosial instagram terhadap minat beli kaum milenial. Simpulan, kepercayaan konsumen pada suatu toko fashion online tentunya akan mempengaruhi terhadap minat beli.
\end{abstract}

Kata Kunci: Instagram, Kepercayaan Konsumen, Media Sosial, Milenial, Minat Beli

\begin{abstract}
The purpose of this study is to measure how much influence social media Instagram and consumer confidence in millennial purchase interest. The variables of this research are Instagram social media (X1), consumer trust (X2) and millennial purchase interest $(Y)$. The method used in this study is a quantitative research method with an associative approach, by distributing 200 online questionnaires to millennials of productive age. The analysis technique used to test the hypothesis in this study is the path analysis. Hypothesis test results show intagram social media and consumer trust have a significant influence on millennial buying interest and mediation hypothesis testing results show that consumer confidence variables mediate Instagram social media on millennial buying interest. Conclusion, consumer confidence in an online fashion store will certainly affect the buying interest.
\end{abstract}

Keywords: Instagram, Consumer Trust, Social Media, Millennials, Purchase Interest

\section{PENDAHULUAN}

Survei Asosiasi Penyelenggara Jasa Internet Indonesia (APJII) yang dilakukan pada tanggal 9 maret sampai dengan 14 april 2019 menyatakan bahwa pengguna internet di Indonesia pada tahun 2018 meningkat sebesar $10.12 \%$ yang awal mulanya pada tahun 2017 pengguna internet sebesar 54,68\% saja kini di tahun 2018 menjadi 
$64,8 \%$ atau sebanyak 171,17 juta jiwa pengguna internet di Indonesia, adapun alasan yang paling sering menggunakan internet yaitu karena menggunakan media sosial (APJII, 2018).

Media sosial telah menjadi bagian yag tak bisa dihindarkan dari kehidupan kita sehari-hari (Taprical \& Kanwar, 2012) dan terlebih lagi kaum milenial merupakan penduduk asli digital yang sangat terobsesi dengan media sosial (Bolton et al., 2017), media sosial juga dapat memberikan peluang bisnis untuk mengembangkan pemasaran yang berbeda dari metode tradisional menjadi media yang menginspirasi konsumen (Ceyhan, 2019) sehingga media sosial dapat memberikan kontribusi yang tinggi pada toko fashion online (Yahya, Hasim, Bahsri, \& Dahari, 2019).

Media sosial mengacu pada sarana interaksi diantara orang-orang dimana mereka membuat, berbagi, dan bertukar informasi dan berbagi berbagai ide (Schiffman \& Wisenbilt, 2018).

Diantara jejaring media sosial lainnya, instagram merupakan salah satu media sosial yang paling sukses menarik perhatian untuk kelompok konsumen baru-baru ini (Ceyhan, 2019). Hal tersebut dilansir dari Bisnis.com yang diakses pada 29 Juni 2019 menyatakan bahwa total pengguna instagram di indonesia yaitu sebanyak 56 juta pengguna (Mudassir, 2019).

Dilansir dari Liputan6.com yang diakses pada 26 Juni 2019 menyatakan bahwa di Indonesia pengguna instagram terbanyak yaitu berusia 18 sampai dengan 24 tahun (Wardani, 2019), usia tersebut termasuk kedalam usia produktif kaum milenial yang dimana usia produktif kaum milenial yaitu berkisaran antara kelahiran 1980 sampai dengan 2000 (Barni, 2019; Hati \& Harefa, 2019; Lestari, 2019; Moreno, Lafuente, Carreón, \& Moreno, 2017), mengacu pada kelahiran kaum milenial menurut peneliti terdahulu maka dapat dikatakan bahwa usia produktif kaum milenial kini berusia 20 sampai dengan 40 tahun.

Minat beli mengacu pada peluang dari suatu barang untuk dikonsumsi atau digunakan dimasa depan (Khan \& Mehmood, 2018), sangat penting bagi penjual online untuk memahami kaum milenial dalam membeli online, karena generasi milenial hampir selalu terhubung dengan internet dan mereka cenderung melakukan pembelian secara online setiap saat kapanpun dan dimanapun (Ladhari, Gonthier, \& Lajante, 2019). 
Walaupun pengguna internet di Indonesia sebanyak 171.17 juta jiwa akan tetapi masih rendahnya tingkat pembelian secara online, hal tersebut dibuktikan dengan data yang diberikan oleh Asosiasi Penyelenggara Jasa Internet Indonesia (APJII) sebesar $58,8 \%$ dari jumlah total pengguna internet di Indonesia belum pernah melakukan transaksi secara online, kurangnya minat beli kaum milenial di tentunya karena kurangnya rasa kepercayaan konsumen terhadap transaksi online (APJII, 2018).

Kepercayaan konsumen tentunya menjadi prinsip yang penting dalam berbagai aktivitas bisnis, mempetahankan kepercayaan terhadap konsumen tentunya akan mempengaruhi tingkah laku konsumen terhadap minat beli (Tarmedi, Sulastri, Sumiyati, \& Dirgantari, 2018). Sehingga, kepercayaan konsumen sangat mempengaruhi minat beli secara online (Rosdiana, Haris, \& Suwena, 2019), hal tersebut juga dapat dilihat dari hasil survei Asosiasi Penyelenggara Jasa Internet Indoensia (APJII) menyatakan bahwa sebesar $17.1 \%$ transaksi melalui internet tidak aman, 9.5\% menyatakan barang khawatir tidak sampai dan sebesar 9\% menyatakan khawattir karena barang tidak sesuai (APJII, 2018).

Hal tersebut ditemukan oleh peneliti sebagai landasan dalam penelitian ini didukung data yang telah di dapat dilapangan. Pada penelitian (Macharia \& Cheng, 2019) memiliki hasil bahwa media sosial instagram berpengaruh terhadap kepercayaan dan pada gilirannya kepercayaan memiliki pengaruh terhadap niat pembelian.

Pada penelitian (Ardiansyah et al., 2019; Astuti et al., 2019; Diebes \& Iriqat, 2019; Imtiaz et al., 2019; Indika \& Jovita, 2017; Macharia \& Cheng, 2019; Mainardes et al., 2018) yang menunjukan hasil bahwa media sosial mempunyai pengaruh terhadap minat beli.

Pada penelitian (Curvelo et al., 2019; Dewi te al., 2016; Jiang et al., 2019; Liu et al., 2019; Rosdiana et al., 2019) menunjukan hasil bahwa kepercayaan konsumen memiliki pengaruh terhadap minat beli. Akan tetapi pada penelitian (Astutik, 2018) yang berjudul "the effect cosmetic products in surabaya with brand attitude mediation" menunjukan hasil bahwa pengaruh secara langsung variabel media sosial berpengaruh langsung terhadap minat beli tetapi tidak signifikan. Sehingga, Penelitian ini bertujuan untuk membuktikan kepercayaan konsumen menjadi mediasi media sosial instagram terhadap minat beli kaum milenial. 


\section{KAJIAN TEORI}

\section{Media Sosial Instagram}

(Ryan, 2014) menyatakan bahwah Media sosial merupakan istilah umum untuk perangkat lunak dan layanan berbasis web yang memungkinkan pengguna untuk berkumpul secara online, bertukar fikiran, berdikusi, berkomunikasi, dan berpartisipasi dalam segala hal.

(Wicaksono, 2017) mengemukakan bahwa "media sosial instagram salah satu media yang kerap digunakan dalam aktivitas kegiatan promosi di era modern". Media sosial merupakan bagian penting dari suatu model komunikasi yang di perbarui (Solomon, Marshall, \& W.stuart, 2018).

Adapun dimensi dalam mengukur media sosial yaitu: 1) Contect yaitu sebuah kejelasan pesan yang dapat diterima konsumen (Abzari, Ghassemi, \& Vosta, 2014; chirs haeuer dalam Arief \& Millianyani, 2015; Astuti \& Renwarin, 2019), 2) Communication yaitu berbagi cerita atau merespon (Abzari et al., 2014; chirs heuer dalam Arief \& Millianyani, 2015; Astuti \& Renwarin, 2019), 3) Collaboration yaitu kerjasama antara penjual dan pembeli (chirs heuer dalam Arief \& Millianyani, 2015), 4) Connection yaitu hubungan (chirs heuer dalam Arief \& Millianyani, 2015).

(Mainardes \& Cardoso, 2019) menyatakan bahwa penggunaan media sosial secara positif mempengaruhi kepercayaan, dan kepercayaan pada gilirannya memiliki pengaruh positif pada minat beli.

\section{Kepercayaan Konsumen}

(Hong \& Cha, 2013) mengemukakan bahwa kepercayaan konsumen didefinisikan sebagai keyakinan bahwa pedagang online tidak akan berprilaku oportunistik dan lingkungan e-commerce cukup aman untuk menyediakan transaki bebas resiko.

(Schiffman \& Wisenbilt, 2018) menyatakan bahwa "kepercayaan mengandalkan pedagang untuk menyelesaikan transaksi pembelian secara sukses, mempercayai kinerja situs, merasa bahwa pedagang dapat di andalkan".

(Putra, Ramdan, \& Mulia, 2019) menyatakan bahwa faktor yang harus diperhatikan penjual ialah kepercayaan, karena ketika konsumen berbelanja secara 
online mereka tentunya sudah memberikan kepercayaan ataupun harapan terhadap penjual tentang apa yang mereka inginkan.

Adapun dimensi untuk mengukur kepercayaan yaitu: 1) Integrity yaitu kecenderungan menepati janji (Anwar \& Adidarma, 2016; Özen, 2019; Widjajanta \& Haekal, 2016), 2) benevolencen yaitu perhatian dan motivasi dalam memberikan kepuasan (Anwar \& Adidarma, 2016; Özen, 2019; Widjajanta \& Haekal, 2016), 3) competence yaitu kemampuan melayani (Anwar \& Adidarma, 2016; Özen, 2019), 4) predictability yaitu konsistensi kehandalan penjual dapat dipercaya (Anwar \& Adidarma, 2016).

(Tarmedi et al., 2018) menyatakan bahwa keprcayaan merupakan prinsip penting dalam berbagai hal aktivitas bisnis, mempertahankan kepercayaan sangat penting karena mempengaruhi minat beli. Sehingga kepercayaan konsumen memiliki pengaruh yang signifikan dan positif terhadap minat beli (Curvelo et al., 2019; Dewi et al., 2016; Jiang et al., 2019; Liu et al., 2019; Rosdiana et al., 2019).

\section{Minat Beli}

(Kim \& Ko, 2012) mendefiniskan bahwa minat beli merupakan suatu kombinasi antara minat dan kemungkinan konsumen untuk membeli suatu produk. Sedangkan (Khan \& Mehmood, 2018) menyatakan bahwa minat beli mengacu pada peluang dari sutau barang untuk dikonsumsi atau digunakan dimasa depan. (Astuti, 2016) menyatakan bahwa "minat beli merupakan tingkat konsumen untuk bertindak sebelum memutuskan untuk melakukan pembelian".

Adapun dimensi minat beli yaitu 1) intensitas pencarian informasi (Astutik, 2018; Ferdinand, 2014), 2) keinginan segera membeli (Abzari et al., 2014; Astutik, 2018; Ferdinand, 2014), 3) keinginan preferensial (Abzari et al., 2014; Ferdinand, 2014), 4) keinginan referensi (Abzari et al., 2014).

\section{Milenial}

Generasi milenial lahir pada tahun 1980 sampai dengan tahun 2000 (Barni, 2019; Hati \& Harefa, 2019; Lestari, 2019; Moreno et al., 2017), dimana generasi ini dikenal sebagai net generation, digital native, dan generation $C$ (OR Connected Generation) (Chuah, Marimuthu, Kandampully, \& Bilgihan, 2017), ada juga beberapa 
pepatah mengatakan bahwa generasi milenial yaitu baby-bom generation dimana generasi ini lebih toleran terhadap keragaman ras dan lebih pintar dari pendahulunya secara keseluruhan, dan juga diberdayakan oleh jangkaun internet.

Oleh karena itu, media sosial mempengaruhi kepercayaan konsumen dan kepercayaan konsumen pada gilirannya mempengaruhi minat beli kaum milenial (Mainardes \& Cardoso, 2019), dan media sosial berpengaruh terhadap minat beli kaum milenial (Astuti \& Renwarin, 2019; Indika \& Jovita, 2017; Macharia \& Cheng, 2019), serta hasil penelitian (Astutik, 2018) menyatakan bahwa hasil pengaruh langsung media sosial terhadap minat beli berpengaruh tetapi tidak signifikan.

\section{METODE PENELITIAN}

Pada penelitian dilakukan di @ Arpe Project yang merupakan toko fashion online di Instagram yang dikhususkan untuk kaum milenial. Metode yang digunakan pada penelitian ini ialah metode asosiatif dengan menggunakan software IBM SPSS 24 dan PROCESS Versi 3.4. Adapun populasi yang digunakan oleh peneliti yaitu kaum milenial yang sudah mengikuti akun instagram Arpe Project berusia 20 sampai dengan 40 tahun, peneliti menggunakan purposive sampling dengan melakukan penyebaran kuesioner kepada 200 responden.

\section{HASIL PENELITIAN}

\section{Uji Kelayakan Model}

Tabel 1 Hasil Uji F

\begin{tabular}{|c|c|c|c|c|c|c|}
\hline \multicolumn{7}{|c|}{ ANOVA $^{a}$} \\
\hline Model & & Sum Of Square & df & Mean Square & $\mathrm{F}$ & Sig. \\
\hline \multirow[t]{3}{*}{1} & Regression & 1881.458 & 1 & 1881.45 & 4939.291 & $.000^{\mathrm{b}}$ \\
\hline & Residual & 75.422 & 198 & .381 & & \\
\hline & Total & 1956.880 & 199 & & & \\
\hline \multicolumn{7}{|c|}{ a.Dependent Variable: Kepercayaan Konsumen } \\
\hline \multicolumn{7}{|c|}{ b. Predictors: (constat), media sosial instagram } \\
\hline \multicolumn{7}{|c|}{ ANOVA $^{\text {a }}$} \\
\hline Model & & Sum Of Squares & df & Mean Square & $\mathrm{F}$ & Sig. \\
\hline \multirow[t]{3}{*}{2} & Regression & 1843.750 & 2 & 921.875 & 3084.908 & $.000^{\mathrm{b}}$ \\
\hline & Residual & 58.870 & 197 & .299 & & \\
\hline & Total & 1902.620 & 199 & & & \\
\hline \multicolumn{7}{|c|}{ a.Dependent Variable: minat beli } \\
\hline b. & Predictors: & nstant), kepercaya & kons & men, media sosial & instagram & \\
\hline
\end{tabular}


Pada penelitian ini terdapat hasil dari uji $F$ pada model 1 yaitu $F_{\text {hitung }} 4939.29>$ $F_{\text {tabel }} 3.89$, selanjutnya pada model $2 F_{\text {hitung }} 3084.908>F_{\text {tabel }} 3.04$ sehingga dapat disimpulkan bahwa hipotesis anova ini dapat diterima dan dinyatakan layak unuk menjelaskan variabel dependen yang dianalisis karena nilai $F_{\text {hitung }}$ lebih besar dari $F_{\text {tabel}}$.

Tabel 2 Hasil Koefisien Determinasi

\begin{tabular}{lcccc}
\hline \multicolumn{4}{c}{ Model Summary } \\
\hline Model & $\mathrm{R}$ & $\mathrm{R}$ Square & Adjusted R Square & Std. Error of the estimate \\
\hline 1 & $.981^{\mathrm{a}}$ & .961 & .961 & .61718 \\
a. Predictors: (constant), media sosial instagram & \\
\hline
\end{tabular}

\begin{tabular}{ccccc}
\multicolumn{4}{c}{ Model Summary } \\
\hline Model & R & R Square & Adjusted R Square & Std. Error of the estimate \\
\hline 2 & $.984^{\mathrm{a}}$ & .969 & .969 & .54666
\end{tabular}

a.Predictors: (constant), kepercayaan konsumen, media sosial instagram

Hasil R pada model 1 menunjukan hasil sebesar 0.981 yang memiliki arti adanya hubungan yang tinggi antara variabel kepercayaan konsumen (X2) terhadap media sosial intagram (X1), adapun pada nilai $\mathrm{R}^{2}$ yaitu 0.961 yang memiliki arti bahwa pengaruh media sosial instagram terhadap kepercayaan konsumen sebesar $96.1 \%$ sedangkan sisanya $3.9 \%$ dipengaruhi oleh variabel lain yang tidak terdapat pada penelitian ini.

Pada model 2 hasil $\mathrm{R}$ menunjukan hasil sebesar 0.984 yang memiliki arti adanya hubungan yang tinggi antara minat beli kaum milenial (Y) terhadap media sosial instagram (X1) dan kepercayaan konsumen (X2). Adapun pada nilai $\mathrm{R}^{2}$ yaitu sebesar 0.969 yang memiliki arti bahwa pengaruh media sosial intagram (X1) dan kepercayaan konsumen (X2) terhadap minat beli kaum milenial (Y) yaitu sebesar 96.9\% sedangkan sisanya $3.1 \%$ dipengaruhi variabel lain yang tidak terdapat pada penelitian ini.

\section{Uji Hipotesis}

Media sosial instagram terhadap kepercayaan konsumen diterima berpengaruh positif dan signifikan, hasil menunjukan sebesar $(0.985, p<0.0000)$ hal tersebut sejalan dengan penelitian (Mainardes \& Cardoso, 2019). Sehingga memmiliki arti bahwa media sosial instagram yang baik akan mempengaruhi kepercayaan konsumen khusunya kaum milenial terhadap suatu toko fashion online. 
Kepercayaan konsumen terhadap minat beli kaum milenial berpengaruh positif dan signifikan, hasil menunjukan sebesar $(0.532, p<0.0000)$. yang memiliki arti bahwa jika konsumen merasa percaya terhadap suatu online shop tentunya akan menimbulkan minat terhadap minat beli hal tersebut juga serupa dengan hasil penelitian (Rosdiana et al., 2019) yang menyatakan bahwa keprcayaan pada memiliki pengaruh terhadap minat beli kaum milenial.

Adapun pengujian hipotesis menggunakan uji $\mathrm{T}$ menunjukan hasil bahwa media sosial instagram (X1) memiliki pengaruh terhadap kepercayaan konsumen (X2) dengan nilai $\mathrm{T}_{\text {hitung }} 70.280>\mathrm{T}_{\text {tabel }} 1.97$ dengan nilai sig. 0.000 , selanjutnya pada pengujian kepercayaan konsumen (X2) terhadap minat beli kaum milenial (Y) dengan nilai Thitung $8.460>$ Ttabel 1.97 dengan nilai sig. 0.000 .

Tabel 3 Koefisien Regresi, Standar Error, dan Uji T

\begin{tabular}{ccccccccc}
\hline & \multicolumn{3}{c}{ Kepercayaan Konsumen (X2) } & \multicolumn{3}{c}{ Minat Beli Kaum Milenial (Y) } \\
\hline & Coeff & SE & T & P-Value & Coeff & SE & T & P-Value \\
\hline $\begin{array}{c}\text { Media Sosial } \\
\text { Instagram (X1) }\end{array}$ & 0.985 & 0.014 & 70.280 & 0.000 & - & - & - & - \\
\hline $\begin{array}{c}\text { Kepercayaan } \\
\text { Konsumen (X2) }\end{array}$ & - & - & - & - & 0.532 & 0.062 & 8.460 & 0.000 \\
\hline
\end{tabular}

Pembahasan selanjutnya untuk menjawab hipotesis 3 yaitu ada pengaruh kepercayaan konsumen memediasi media sosial instagram terhadap minat beli kaum milenial. Untuk menentukan terdapatnya mediasi pada hipotesis 3 yaitu apabila BootsLLCI dan BootULCI tidak mencakup nilai nol (0) maka hipotesis diterima dan terdapat mediasi (Hayes, 2013).

Tabel 4. Pengaruh Tidak Langsung Media Sosial Instagram terhadap Minat Beli

\begin{tabular}{lcccc}
\hline & effect & BootSE & BootsLLCI & BootsULCI \\
\hline Melalui Kepercayaan Konsumen & 0.524 & 0.089 & 0.338 & 0.687 \\
\hline
\end{tabular}

Berdasarkan hasil tabel 4 hasil pengaruh tidak langsung media sosial instagram terhadap minat beli kaum milenial dimediasi oleh kepercayaan konsumen sebesar 0.524 dan dilihat dari hasil BootsLLCI 0.338 dan BootsULCI 0.687 dengan Convidence Interval 95\% dapat dikatakan bahwa kepercayaan konsumen (X2) memediasi antara media sosial instagram (X1) terhadap minat beli kaum milenial (Y). 


\section{PEMBAHASAN}

Pengaruh tidak langsung media sosial instagram terhadap minat beli kaum milenial dimediasi oleh kepercayaan konsumen sebesar 0.524 dan dilihat dari hasil BootsLLCI 0.338 dan BootsULCI 0.687 dengan Convidence Interval 95\% dapat dikatakan bahwa kepercayaan konsumen (X2) memediasi antara media sosial instagram (X1) terhadap minat beli kaum milenial (Y).

Media sosial mengacu pada sarana interaksi diantara orang-orang dimana mereka membuat, berbagi, dan bertukar informasi dan berbagi berbagai ide (Schiffman \& Wisenbilt, 2018).

Diantara jejaring media sosial lainnya, instagram merupakan salah satu media sosial yang paling sukses menarik perhatian untuk kelompok konsumen baru-baru ini (Ceyhan, 2019). Hal tersebut dilansir dari Bisnis.com yang diakses pada 29 Juni 2019 menyatakan bahwa total pengguna instagram di indonesia yaitu sebanyak 56 juta pengguna (Mudassir, 2019).

Dilansir dari Liputan6.com yang diakses pada 26 Juni 2019 menyatakan bahwa di Indonesia pengguna instagram terbanyak yaitu berusia 18 sampai dengan 24 tahun (Wardani, 2019), usia tersebut termasuk kedalam usia produktif kaum milenial yang dimana usia produktif kaum milenial yaitu berkisaran antara kelahiran 1980 sampai dengan 2000 (Barni, 2019; Hati \& Harefa, 2019; Lestari, 2019; Moreno, Lafuente, Carreón, \& Moreno, 2017), mengacu pada kelahiran kaum milenial menurut peneliti terdahulu maka dapat dikatakan bahwa usia produktif kaum milenial kini berusia 20 sampai dengan 40 tahun.

Minat beli mengacu pada peluang dari suatu barang untuk dikonsumsi atau digunakan dimasa depan (Khan \& Mehmood, 2018), sangat penting bagi penjual online untuk memahami kaum milenial dalam membeli online, karena generasi milenial hampir selalu terhubung dengan internet dan mereka cenderung melakukan pembelian secara online setiap saat kapanpun dan dimanapun (Ladhari, Gonthier, \& Lajante, 2019). 


\section{SIMPULAN}

Berdasarkan penelitian yang telah dilakukan, peneliti menemukan beberapa kesimpulan untuk menjawab pertanyaan pada penelitian ini dengan teknik analisis jalur diketahui bahwa terdapat pengaruh antara media sosial instagram terhadap kepercayaan konsumen sebesar 0.985 atau $98.5 \%$ yang memiliki arti bahwa media sosial instagram yang baik tentunya akan menimbulkan rasa kepercayaan konsumen terhadap media sosial instagram tersebut. Selanjutnya kepercayaan konsumen terhadap minat beli memiliki pengaruh sebesar 0.532 atau $53.2 \%$ yang memiliki arti bahwa kepercayaan konsumen pada suatu toko fashion online tentunya akan mempengaruhi terhadap minat beli.

Pengujian hipotesis mediasi menunjukan bahwa kepercayaan konsumen memediasi media sosial instagram terhadap minat beli sebesar 0.524 atau $52.4 \%$ dan hasil BootsLLCI 0.338 dan BootsULCI 0.687 dimana hasil tidak mencakup nilai nol maka dapat dikatakan bahwa terdapat pengaruh mediasi, hal tersebut menunjukan bahwa media sosial yang baik tentunya akan menimbulkan kepercayaan pada konsumen, setelah konsumen memiliki kepercayaan terhadap media sosial tentu saja akan berdampak pada minat beli.

\section{DAFTAR PUSTAKA}

Abzari, M., Ghassemi, R. A., \& Vosta, L. N. (2014). Analysing the Effect of Social Media on Brand Attitude and Purchase Intention: The Case of Iran Khodro Company. Procedia - Social and Behavioral Sciences, 143, 822-826. https://doi.org/10.1016/j.sbspro.2014.07.483

Anwar, R., \& Adidarma, W. (2016). Pengaruh Kepercayaan dan Resiko pada Minat Beli Belanja Online. Jurnal Manajemen Dan Bisnis Sriwajaya, 14, 2

APJII. (2018). Survei APJII: Penetrasi Pengguna Internet di Indonesia

Ardiansyah, P. W., \& Nilowardono, S. (2019). The Influence of Brand Image, Product Innovation and Social Media Marketing on Samsung Smartphone 's Buying Interest: Case Study on Narotama University Students Indonesia Top 5 Smartphone Companies by Year over Year ( YOY ) Market Share Comparation , 2. Internasional Jurnal of Enterpreneurship and Business Development, 2(2), 210217

Arief, G. M., \& Millianyani, H. (2015). Pengaruh Social Media Marketing melalui Instagram terhadap Minat Beli Konsumen Sugar Tribe. E-Proceeding of Management, 2(3), 2581-2587

Astuti, D., \& Renwarin, J. M. J. (2019). Memaksimalisasi Minat Beli Kaum Milenial Jakarta di Era Booming Sosial Media. Jurnal Ilmiah Manajemen EMOR, 3(1), 4262 
Astuti, R. L. M. B. (2016). Pengaruh Promosi Online dan Celebrity Endorser terhadap Minat Beli Konsumen Tas Online Shop Fani House. Universitas Diponegoro

Astutik, Y. (2018). Pengaruh Media Sosial terhadap Minat Beli Konsumen Wardah Kosmetik Surabaya dengan Mediasi Sikap Merek. Sekolah Tinggi Ilmu Ekonomi Perbarnas

Barni, M. (2019). Tantangan Pendidik di Era Millenial. Jurnal Teansformatif, 3(1), 99116

Bolton, R. N., Parasuraman, A., Hoefnagels, A., Migchels, H., Kabadayi, S., Gruber, T., \& Solnet, D. (2017). Understanding Generation Y and their use of Social Media: A Review and Research Agenda. Management Research Review, 40(3), 352-367. https://doi.org/https://doi.org/10.1108/MRR-01-2016-0019 Downloaded

Ceyhan, A. (2019). The Impact of Perception Related Social Media Marketing Applications on The Impact of Perception Related Social Media Marketing Applications on Consumers ' Brand Loyalty and Purchase Intention. Emerging Markets Journal, 7(2). https://doi.org/10.5195/emaj.2018.134

Chuah, S. H. W., Marimuthu, M., Kandampully, J., \& Bilgihan, A. (2017). What Drives Gen Y loyalty? Understanding the Mediated Moderating Roles of Switching Costs and Alternative Attractiveness in the Value-Satisfaction-Loyalty Chain. Journal of Retailing and Consumer Services, 36(February), 124-136. https://doi.org/10.1016/j.jretconser.2017.01.010

Curvelo, I. C. G., Watanabe, E. A. de M., \& Alfinito, S. (2019). Purchase Intention of Organic Food under the Influence of Attributes, Consumer Trust and Perceived Value. Revista de Gestão, 26(3), 198-211

Dewi, R. Y., Yulianeu, Tri, A. H., \& Gagah, E. (2016). Pengaruh Kepercayaan Konsumen, Kemudahan dan Kualitas Informasi terhadap Keputusan Pembelian Secara Online dengan Minat Beli sebagai Variabel Intervening (Studi pada pengguna situs jual beli Bukalapak.com). Journal Ilmiah, 1, 1-7

Diebes, H. M. Y., \& Iriqat, R. A. M. (2019). Social Media As a Strategic Marketing Communication Tool in Palestinian Mobile Telecom Companies - Business To Customers Relationship Perspective. International Review of Management and Marketing, 9(3), 31-40. https://doi.org/10.32479/irmm.7714

Ferdinand, A. (2014). Metode Penelitian Manajemen Pedoman Penelitian untuk Penulisan Skripsi Tesisdan Disertasi Ilmu Manajemen (Edisi Keli). Semarang: Badan Penerbit Universitas Diponegoro.

Hati, S. W., \& Harefa, W. S. (2019). Analisis Faktor-Faktor yang Mempengaruhi Minat Berinvestasi di Pasar Modal bagi Generasi Milenial (Studi pada Mahasiswi Jurusan Manajemen Bisnis Politeknik Negeri Batam). Journal of Business Administration, $3(2), 281-295$

Hayes, A. F. (2013). Introduction to Mediation, Moderation, and Conditional Process Analysis: a Regression-Based Approach. In Datamation (Vol. 31). https://doi.org/10.4324/9781351239585-39

Hong, I. B., \& Cha, H. S. (2013). The Mediating Role of Consumer Trust in an Online Merchant in Predicting Purchase Intention. International Journal of Information Management, 33(6), 927-939. https://doi.org/10.1016/j.ijinfomgt.2013.08.007

Imtiaz, R., Ul Ain Kazmi, S. Q., Amjad, M., \& Aziz, A. (2019). The Impact of Social Network Marketing on Consumer Purchase Intention in Pakistan: A study on female apparel. Management Science Letters, 9(7), 1093-1104. https://doi.org/10.5267/j.msl.2019.3.015 
Indika, D. R., \& Jovita, C. (2017). Media Sosial Instagram sebagai Sarana Promosi untuk Meningkatkan Minat Beli Konsumen. Jurnal Bisnis Terapan, 1(01), 25. https://doi.org/10.24123/jbt.v1i01.296

Jiang, C., Rashid, R. M., \& Wang, J. (2019). Investigating the Role of Social Presence Dimensions and Information Support on Consumers' Trust and Shopping Intentions. Journal of Retailing and Consumer Services, 51(June), 263-270. Retrieved from https://doi.org/10.1016/j.jretconser.2019.06.007

Khan, F., \& Mehmood, A. (2018). Purchase Intention Drivers Fr Private Label Brands In Pakistan. 20(2), 298-317

Kim, A. J., \& Ko, E. (2012). Do Social Media Marketing Activities Enhance Customer Equity? An Empirical Study of Luxury Fashion Brand. Journal of Business Research, 65(10), 1480-1486. https://doi.org/10.1016/j.jbusres.2011.10.014

Ladhari, R., Gonthier, J., \& Lajante, M. (2019). Generation Y and Online Fashion Shopping : Orientations and Profiles. Journal of Retailing and Consumer Services, 48, 113-121. https://doi.org/10.1016/j.jretconser.2019.02.003

Lestari, I. N. F. (2019). Hubungan antara Subjective Well-Being dengan Kepuasan Kerja Karyawan Generasi Milenial di Pt. Telkom Regional IV JATENG \& DIY. Universitas Diponegoro

Liu, C., Bao, Z., \& Zheng, C. (2019). Exploring Consumers' Purchase Intention in Social Commerce: an Empirical Study Based on Trust, Argument Quality, and Social Presence. Asia Pacific Journal of Marketing and Logistics, 31(2), 378-397

Macharia, H. W., \& Cheng, Y. (2019). How do Social Media Marketing Activities Influence Customer Equity and Purchase Intention : Linnaeus University

Mainardes, E. W., \& Cardoso, M. V. (2019). Effect of the Use of Social Media in Trust, Loyalty and Purchase Intention in Physical Stores. International Review of Retail, Distribution and Consumer Research, 29(4), 456-477. https://doi.org/10.1080/09593969.2019.1583593

Moreno, F. M., Lafuente, J. G., Carreón, F. Á., \& Moreno, S. M. (2017). The Characterization of the Millennials and Their Buying Behavior. International Journal of Marketing Studies, 9(5), 135. https://doi.org/10.5539/ijms.v9n5p135

Mudassir, R. (2019). Daftar Pengguna Instagram Terbanyak di Dunia, Indonesia di Urutan Berapa? Retrieved from 29 Juni website: https://teknologi.bisnis.com/read/20190629/84/939306/daftar-pengguna-instagramterbanyak-di-dunia-indonesia-di-urutan-berapa

Özen, E. (2019). The Concept of Trust in Socio-Economic Life. European Journal of Marketing and Economics, 2(2), 69. https://doi.org/10.26417/ejme-2019.v2i2-72

Putra, T. M, Ramdan, A. M, \& Mulia, F. (2019). Analisis e-Service dan Kepercayaan Konsumen terhadap Kepuasan Konsumen Pengguna Website. Journal of Business, Management and Accounting, 1, 1-9

Ramadhan, A. F., \& Zuliestiana, D. A. (2018). Analisis Pemanfaatan Youtube Social Media Marketing Gojek dalam Mempengaruhi Minat Beli dan Loyalitas terhadap brand. Jurnal Mitra Manajemen, 2(4), 273-285. Retrieved from http://ejurnalmitramanajemen.com/index.php/jmm/article/view/125/69

Rosdiana, R., Haris, I. A., \& Suwena, K. R. (2019). Pengaruh Kepercayaan Konsumen terhadap Minat Beli Produk Pakaian Secara Online. Jurnal Pendidikan Ekonomi Undiksha, 11(1)

Ryan, D. (2014). Understanding Digital Marketing (3rd ed.). London Philadelphia New Delhi: Koganpage 
Schiffman, L. G., \& Wisenbilt, J. 1. (2018). Consumer Behavior (11th ed.). Global Edition: Pearson

Solomon, M. R., Marshall, G. W., \& Stuart, E. (2018). Marketing Real People, Real Choices (9th ed.). Pearson

Taprical, V., \& Kanwar, P. (2012). Understanding Social Media. Retrieved from http://search.ebscohost.com/login.aspx?direct=true \&db=bth\&AN=35132458\&site $=$ ehost-live

Tarmedi, E., Sulastri, S., Sumiyati, S., \& Dirgantari, P. D. (2018). Factors Affecting Customer Trust and Their Impact on Customer Behavioural Intention: A Study of Social Commerce in Indonesia. Pertanika Journal of Social Sciences and Humanities, 26, 63-74

Wardani, A. S. (2019). Jumlah Pengguna Instagram dan Facebook Indonesia terbesar ke 4 di Dunia. Retrieved from 26 juni website: https://m.liputan6.com/tekno/read/3998624/jumlah-pengguna-instagram-danfacebook-indonesia-terbesar-ke-4-di-dunia

Wicaksono, M. A. (2017). Pengaruh Media Sosial Instagram @wisatadakwahokura terhadap Minat Berkunjung Followers. JOM FISIP, 4(2), 1-13

Widjajanta, B., \& Haekal, A. (2016). Pengaruh Kepercayaan dan Persepsi Risiko terhadap Minat Membeli Secara Online pada Pengunjung Website Classifieds di Indonesia. Journal Of Business Management \& Entrepreneur Education, 1(1), 181-193

Yahya, S. F. H., Hasim, N. A., Bahsri, N., \& Dahari, N. A. (2019). The Effect of Sales Promotion Strategy on Online Fashion Shopping Behavior among Employee of Sahawan Sdn Bhd. Global Business and Management Research: An International Journal, 11(2), 1-419 